\title{
Investigation of ergonomic working conditions of sewing and cutting machine operators of clothing industry
}

DOI: 10.35530/IT.072.03.1723

\begin{abstract}
REZUMAT
Investigation of ergonomic working conditions of sewing and cutting machine operators of clothing industry

The textile industry is a very labour intensive industry which mainly comprises of small and medium enterprises (SMEs). In developing countries, usually occupational health and safety programs are focused on large-scale organisations. A cross-sectional study on evaluating ergonomics risk factors associated with task performing strategies has been carried out at cutting and sewing units of a garment industry organisation. A reliable direct observational ergonomics risk assessment method Rapid Entire Body Assessment (REBA) was used to find out the risk associated with working postures adopted by the workers. Data was collected through physical observations, walkthrough, interviews, and video recordings. Data analysis was carried out on 180 selected postures by using REBA method. It concluded that overall working strategies were poorly designed as more than $30 \%$ of postures highlighted a high level of risk of MSDs that necessitates immediate investigation for improvement. Major causes of risk were linked with the postural movements attached with the wrist, lower arm, and neck. The findings of the study add to the understanding of working conditions of cutting and sewing activities at garment manufacturing industries, these could help in the design of ergonomics interventions for reducing musculoskeletal symptoms and improving job quality which eventually increases work productivity.
\end{abstract}

Keywords: musculoskeletal disorders, textile industry, sewing and cutting machine operators, REBA

Investigarea condițiilor ergonomice de lucru ale operatorilor de mașini de cusut și croit din industria de îmbrăcăminte

Industria textilă este o industrie care implică muncă fizică intensivă, fiind compusă în principal din întreprinderi mici și mijlocii (IMM-uri). În țările în curs de dezvoltare, programele de sănătate și securitate ocupațională se concentrează de obicei pe organizații la scară largă. Un studiu transversal privind evaluarea factorilor de risc ergonomici asociați cu strategiile de îndeplinire a sarcinilor a fost realizat în secțiile de croire și de asamblare ale unei organizații din industria de îmbrăcăminte. S-a folosit o metodă fiabilă de evaluare a riscului ergonomic prin observare directă, respectiv "Evaluarea rapidă a întregului corp" (REBA), pentru a afla riscul asociat posturilor de lucru adoptate de lucrători. Datele au fost colectate prin observații fizice, inspecție, interviuri și înregistrări video. Analiza datelor a fost efectuată pe 180 de posturi selectate utilizând metoda REBA. S-a concluzionat că strategiile generale de lucru au fost concepute necorespunzător, deoarece mai mult de 30\% din posturi au evidențiat un nivel ridicat de risc privind tulburările musculoscheletice (MSD), care necesită măsuri imediate pentru îmbunătățire. Cauzele majore ale riscului au fost legate de mișcările posturale la încheietura mâinii, brațul inferior și gât. Rezultatele studiului facilitează înțelegerea condițiilor de lucru în secțiile de croire și de asamblare în industria de îmbrăcăminte, putând ajuta la proiectarea ergonomică pentru reducerea tulburărilor musculo-scheletice și la îmbunătățirea calității locului de muncă, ceea ce crește în cele din urmă productivitatea muncii.

Cuvinte-cheie: tulburări musculo-scheletice, industria textilă, operatorii de mașini de cusut și croit, REBA

\section{INTRODUCTION}

\section{Background and objectives of the study}

Economic worth of textile and clothing sector is estimated as $439.1 \mathrm{bn} \$$, where Pakistan is ranked as the 8th largest exporter of textile related products, and the sector supports about $8 \%$ to the gross domestic product (GDP). According to ILO, Garment, Textile, and Footwear industry employ more than 43 million people in developing Asia. At Pakistan, the textile industry has considerable employment contribution, i.e. $30 \%$ of the 49 million workforces of the country and have a competitive edge nationally [1-3]. MSDs are very commonly observed health issue, not only in the textile sector but also in many other sectors all over the world. These affect the quality of work-life and performance of individuals and organisations $[4,5]$. Jobs in garment industry involve prolonged standing or sitting positions, repetitive movements of hands and arms, poor working postures and bad workplace design [6-8]. Sewing machine operators are engaged in repetitive actions of both hands while leaning forward to getting the focus that leads to MSD in the upper limb, back, and neck [5]. 
Currently, there is no study to understand the risk factors attached to the work practices adopted by the sewing and cutting operators of garment industries in Pakistan. To fill this gap, this study aims at examining the working conditions of sewing and cutting machines' operators of the garment industry. To achieve this objective, evaluation of ergonomics risk factors associated with existing working strategies has been carried out through Rapid Entire Body Assessment (REBA) tool.

Work-related musculoskeletal disorders are considered as a major health and safety concern which affects workers' life [9]. The cost of work-related accidents, injuries and illnesses is considerable $(3.9 \%$ of global GDP) whereas according to WHO and ILO, WRMSDs is an international health concern which is found as the third major reason of disability and early retirement [10]. Similarly, European Foundation for the Improvement of Living and Working Conditions (EUROFOUND) concluded that about 60 million workers reportedly suffer from WRMSDs in Europe [11]. WRMSDs have significant economic impact because of lost working days, medical expenditures, and lost productivity $[12,13]$. Additionally, WRMSDs result in injuries, symptoms of pain, and stress at work [14, 15].

Prevalence of WRMSDs in the textile industry, especially garments manufacturing sector has been reported because of the nature of job and working conditions [16]. Based on the working requirements, different body parts like neck, shoulders, back and lower extremities are usually affected because of sitting in a fixed position for prolonged hours, high paced repetitive tasks, difficult gripping positions and [15]. Symptoms of pain in the lower back, shoulder, wrist, elbow, and neck have been reported frequently [17-19]. Previously, the genesis of WRMSDs concluded that there were three sets of risk factors associated with these: physical; psychosocial/organisational and individual factors [20]. In general, occupational health and safety have been highlighted as an area of concern in the textile industry of Pakistan, and $R \& D$ need in the textile industry has been emphasised [21, 22]. Above discussion concludes that symptoms of WRMSDs among the workers of the garment industry are common due to multiple reasons and require the attention of researchers so that suitable interventions could be designed and implemented. At present, there is no study to understand the prevalence of MSDs and related risk factors among sewing and cutting machine operators working in the garment industry of Pakistan.

Techniques used for the assessment of risk factors are broadly categorised into three major domains: self-reports; observational techniques; and direct methods known as instrumental techniques. These techniques are used to analyse working postures, load or force being applied during work, frequency of movement, time duration, exposure to vibration, etc. [23]. The selection of an appropriate method depends upon the requirement and purpose of the study. Some methods like RULA (Rapid Upper Limb
Assessment) [24], LUBA (Postural Loading on Upper Body Assessment) [25] and ULRA (Upper Limb Risk Assessment) [26] can only assess the upper limb or upper body load while others like REBA (Rapid Entire Body Assessment) [27], OWAS (Ovako Working Posture Analysis System) [28], NIOSH Lifting Equations [29] can be used to assess the entire body. REBA is a valid and reliable pen-paper based observation technique that has been frequently used to assess entire body posture along while considering other factors like force, repetitions, and coupling, etc. $[27,30]$.

\section{RESEARCH METHODOLOGY}

The study was conducted in one of the largest garment manufacturing unit located in Lahore, the provincial capital of Punjab, Pakistan. Cutting and sewing activities (containing 34 sub-tasks) of basic 5-pocket denim jeans emphasised for ergonomics risk assessment. As a first step, walk-through investigations, along with the interviews and focus group discussions were carried out for collecting information about work processes, job requirements, workstation design, and feelings of workers about their job. Then working strategies against selected activities (34 sub-tasks) were video recorded. Videos were analysed by the experts and selected snapshots were used for further analysis. The REBA sheet [30] was used to evaluate the selected postures for finding the level of risk. Final REBA scores were calculated based on the severity of the risk, and action categories were determined. Figure 1 and table 1 further explain the research process and REBA action categories.

\begin{tabular}{|c|c|l|}
\hline \multicolumn{3}{|c|}{ Table 1} \\
\hline Level & $\begin{array}{c}\text { REBA } \\
\text { Score }\end{array}$ & \multicolumn{1}{|c|}{ Action required } \\
\hline 0 & 1 & Negligible risk \\
\hline 1 & $2-3$ & Low risk: changes may be needed \\
\hline 2 & $4-7$ & $\begin{array}{l}\text { Medium risk: further Investigation. } \\
\text { Change soon }\end{array}$ \\
\hline 3 & $8-10$ & $\begin{array}{l}\text { High rsk: investigate and implement } \\
\text { change }\end{array}$ \\
\hline 4 & $11+$ & $\begin{array}{l}\text { Very high risk: implement change } \\
\text { NOW }\end{array}$ \\
\hline
\end{tabular}

\section{DATA ANALYSIS}

The feedback provided by the workers during walkthrough, interviews and focus group discussions concluded the presence of the symptoms of musculoskeletal disorders. Sitting position workers complained about pain at their neck, back, wrist and shoulders; whereas standing position workers complained pain at their trunk, legs, and feet. It was also observed that injuries at fingers were a widespread problem. Some other work organization and workspace design-related issues were also highlighted by the workers; for example, long working hours, 


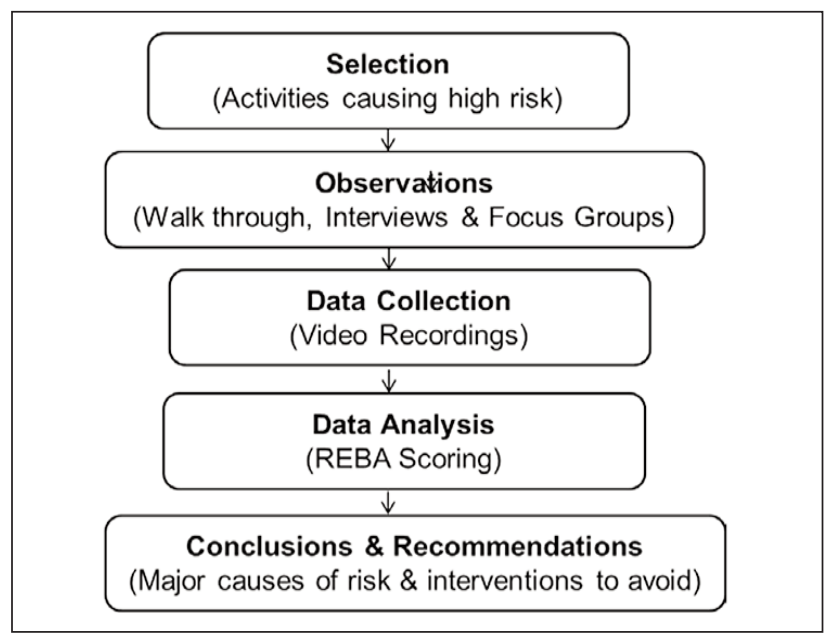

Fig. 1. Research process

repetition of tasks and congested workspace. Especially for sitting workers, workstation design had been found very poor where seats were provided without back support and movement of products were not on a streamlined path. Workers were to move the whole body for picking the material. All these findings helped in selecting appropriate tasks/activities which are physically strenuous for which video recordings were carried out.

Recorded videos were observed by the experts carefully, and snapshots were selected for further analysis. Finally, 180 snapshots were selected for final data analysis. In the REBA score chart, postural codes are assigned against the positions of different body parts like the neck, trunk, leg, upper arm, lower arm, and wrist. Posture score A was calculated with the help of table $A$ and posture score $B$ was calculated with the help of table B. Final score A and B were calculated after incorporating load/force score and coupling score to posture scores $A$ and $B$ respectively. Combining score $A$ and $B$ in table $C$ gives score $C$, which is finally converted into final REBA score after adding activity score. Details about REBA score calculation can be seen in the literature [27, 30]. Final REBA score provides information regarding the severity of the level of risk in a working posture (table 1). It's important to mention that the selection of posture scores against the neck, trunk, leg, upper arm, lower arm, and wrist are based purely on the degree of flexion, extension, abduction, adduction, bending, side flexed, twist and their combinations. Postural movements containing combinations, for example, bent and twist have a relatively higher level of risk and scored high in the scheme.

Figure 2 shows a worker performing the task. It can be seen that the worker is picking up the bundle from the basket placed at the ground. The neck is flexed greater than $20^{\circ}$ with a twist, so according to REBA risk assessment worksheet, the score for the neck will be 3 . Scores against trunk and leg can be found as 4 and 1 respectively. Posture score A can be calculated by combining scores against the neck, trunk, and leg; whereas final Score A will be calculated by adding load/force score in posture score $A$, which is 6. Posture code B can be calculated by finding scores against the movements of upper-arm (2), lower-arm (2) and wrist (2). Score B can be calculated by adding a coupling score (1) into posture score $B$, found to be 4 . Final REBA score is found to be 8 in this case after combining score $A$ and $B$ and adding activity score (1). As per the given picture, REBA score 8 will fall under the category of 'High Risk' where an immediate investigation is required.

\section{RESULTS AND DISCUSSION}

The analysis concluded that the majority of postures fall in the categories of medium, high and very high risk, where more than $30 \%$ fall in the category of high and very high risk. Postures falling under high risk categories (action categories 3 and 4 ) were further analysed so that a more in-depth insight about possible causes of risk could be investigated. Results concluded

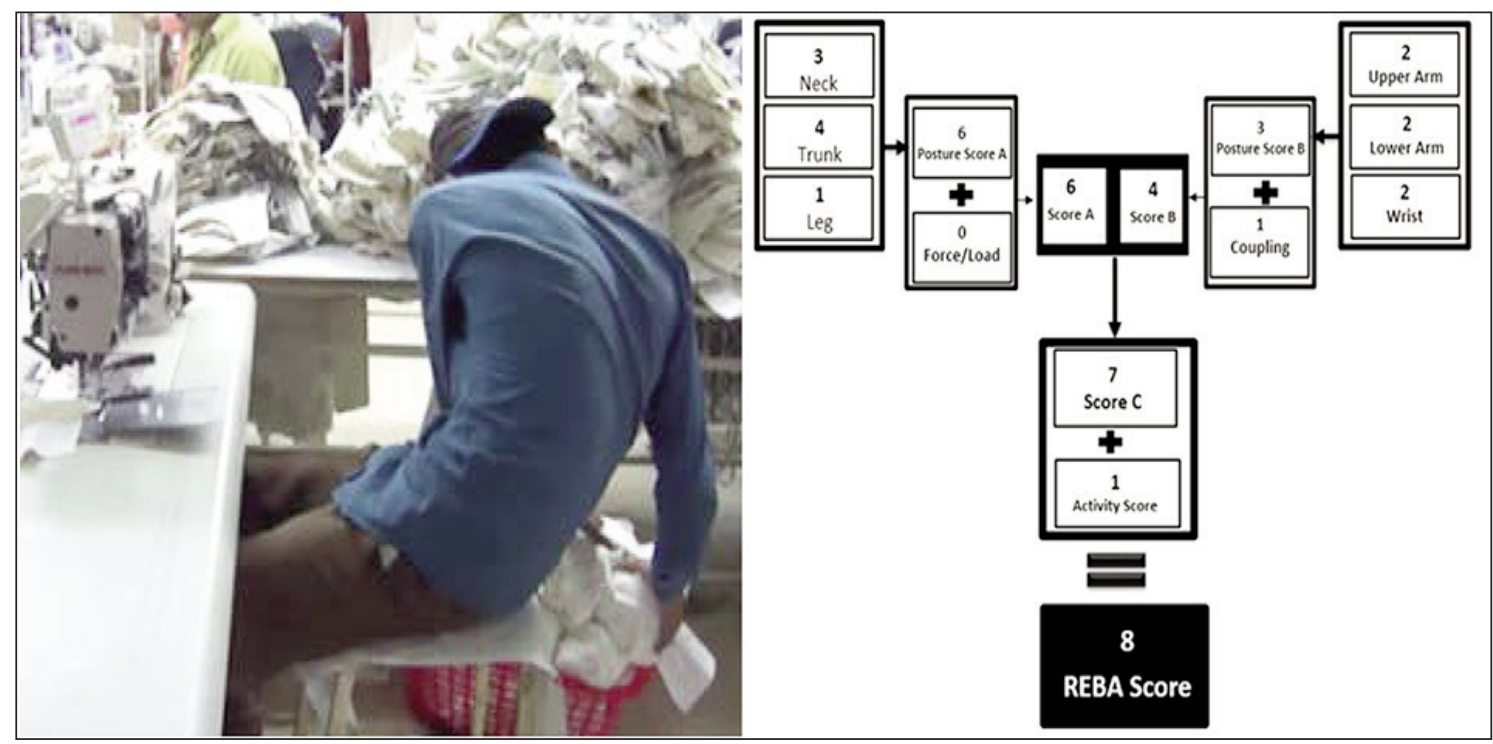

Fig. 2. Calculating REBA score against adopted working posture 
that body parts like wrist, lower arm and neck were more vulnerable to risk as significant percentage of postures $(84.41 \%, 79.31 \%$, and $67.24 \%$ respectively) falling under action categories 3 and 4 belong to these body parts, shown in figure 3 . Postural positions of the trunk and upper arm also played an important role. Complete summary of the analysis is shown in table 2. Descriptions of the code (in table 2) describe the postural position of a specific part of the body. For example, neck posture (code 3 for the neck as per REBA scores) caused high risk is a combination of $>20^{\circ}$ in extension or flexion with twist or side flexed movement. Some sample postures for the trunk, arm and unprotected fingers are shown in figure 4 respectively.
The problem of injuries at fingers was investigated and found that this was because of unguarded cutting blades and lack of the use of protective equipment for fingers. In light of the above results in which primary causes of MSDs have been determined, further recommendations have been developed. It's clear that in garment sewing and cutting activities, major causes of risk are the postural positions of the wrist, lower arm, neck, upper arm, and trunk.

Workers usually adopt awkward working postures that include simultaneous bend and twist movements. Additionally, injuries at fingers are caused due to improper design of cutter and unavailability of protective equipment specific to the cutting activity.

From all this, we may conclude recommendations for avoiding injuries and symptoms of MSDs of garment industry workers performing sewing and cutting operations. For example, improvement in workplace design by providing adequate supports for sitting and standing positions, ergonomically designed chairs, the appropriate height of the table, etc. Simultaneous twist and bend movements of different body parts like neck, trunk, arms, and wrist can be avoided by the smooth flow of materials among the workstation. Proper provision for the placement of materials must be

Fig. 3. Role of different body parts as a cause of risk (REBA action categories 3 \& 4)

Table 2

\begin{tabular}{|c|c|l|}
\hline \multicolumn{3}{|c|}{ POSTURAL DESCRIPTION OF DIFFERENT BODY PARTS (REBA ACTION CATEGORIES 3 \& 4) } \\
\hline Posture & Code & \multicolumn{1}{c|}{ Postural description } \\
\hline Neck & 3 & Combinations of $>20^{\circ}$ in extension or flexion with twist or side flexed \\
\hline Trunk & 4,5 & $\begin{array}{l}\text { Different combinations of } 20^{\circ}-60^{\circ},>60^{\circ} \text { in flexion or extension and twist or side } \\
\text { bending }\end{array}$ \\
\hline Leg & 3,4 & Bilateral or unilateral weight-bearing with knee flexion $30^{\circ}-60^{\circ}$ or $>60^{\circ}$ \\
\hline Load/Force & 3 & $>10 \mathrm{~kg}$ \\
\hline Upper Arm & 4,5 & $\begin{array}{l}\text { Combinations include } 45^{\circ}-90^{\circ},>90^{\circ} \text { flexion with abduction, rotation or shoulder } \\
\text { in raised position }\end{array}$ \\
\hline Lower Arm & 2 & $<60^{\circ}$ flexion or $>100^{\circ}$ flexion \\
\hline Wrist & 2,3 & Combinations of $0-15^{\circ}$ or $>15^{\circ}$ flexion or extension with deviation or twist \\
\hline
\end{tabular}

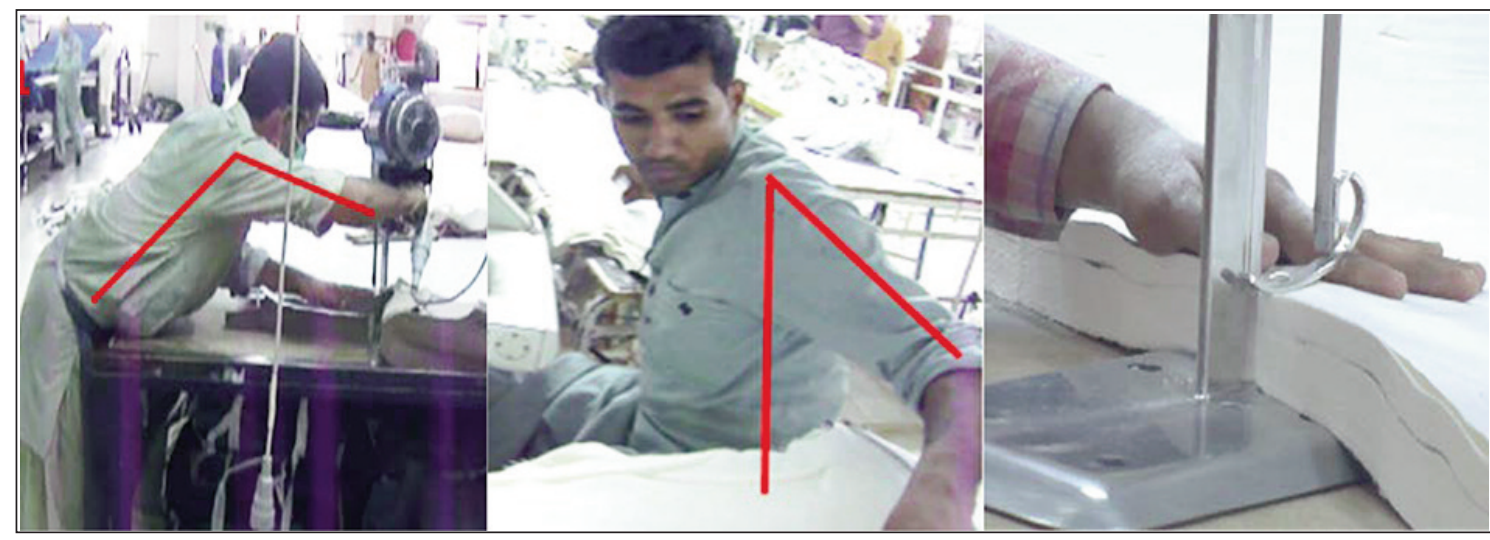

Fig. 4. Captured working strategies showing postural positions 
ensured. Protective equipment for fingers must be ensured along with guarding the cutters. Other issues being highlighted during interviews and focus group discussions might be resolved through flexible working hours and job rotation.

\section{CONCLUSIONS}

The findings of this research highlighted that a significant number of working strategies adopted by sewing and cutting machine operators of garment industry showed a high level of risk for MSDs. The findings revealed that postural positions of the wrist, lower arm, upper arm, trunk, and neck are highly vulnerable to risk. Workers had to adopt working strategies that include simultaneous bend and twist movements due to poor workstation design. Cutting machine operators were exposed to injuries at their fingers because of unguarded cutters and unavailability of customised protective equipment. This research improves the understanding of ergonomics risk factors linked with the working conditions of sewing and cutting machine operators of the garment industry. Moreover, the study helps the managers and designers to consider associated risk factors while designing workplaces and assigning tasks to workers. Furthermore, some interventions have also been discussed for improving overall working conditions and well-being at work.

This study also has some limitations. For example, data has been collected from one industry, and results may differ for other industries. The study can be further extended to consider the impact of work organization, organizational culture, and environmental issues on the well-being in general and musculoskeletal disorders in particular. Further research can be carried out to conduct a comprehensive empirical study for multiple garment industries so that the most reliable significant ergonomics risk factors could be identified.

\section{ACKNOWLEDGEMENT}

We acknowledge the participation and support provided by the industry representatives and employees. The study was supported by UET, Lahore, grant Number ORIC/94ASRB/138.

\section{REFERENCES}

[1] Huynh, P., Developing Asia's garment and footwear industry: Recent employment and wage trends. In: ILO AsiaPacific Garment and Footwear Sector Research Note, 2017, Available at: http://www.ilo.org/asia/publications/issuebriefs/WCMS_581466/lang—en/index.htm [Accessed on June 2019]

[2] Simion, C.-P., et al., Economic and IT determinants of innovative projects in the textiles, wearing apparel, leather and related products industry, In: Industria Textila, 2018, 69, 4, 338-344, http://doi.org/10.35530/IT.069.04.1478

[3] Safeer, A., Abrar, M., Baig, S.A., Basit, A., Zia-ur-rehman, M., Hashim, M., Export competitive analysis of Pakistan garment industry based on GEM model, In: Industria Textila, 2018, 69, 3, 219-229, http://doi.org/ 10.35530/IT.069.03.1457

[4] Buckle, P.W., Jason Devereux, J., The nature of work-related neck and upper limb musculoskeletal disorders, In: Applied Ergonomics, 2002, 33, 207-217, https://doi.org/10.1016/S0003-6870(02)00014-5

[5] Dianat, I., Kord, M., Yahyazade, P.,Karimi, M.A., Stedmon, A.W., Association of individual and work-related risk factors with musculoskeletal symptoms among Iranian sewing machine operators, In: Applied Ergonomics, 2015, 51, 180-188, https://doi.org/10.1016/j.apergo.2015.04.017

[6] Bernard, B.P., Musculoskeletal Disorders and Workplace Factors: A Critical Review of Epidemiologic Evidence for Work-Related Musculoskeletal Disorders of the Neck, Upper Extremity, and Low Back, US Department of Health and Human Services, Cincinnati, OH, 1997, Available at: https://www.cdc.gov/niosh/docs/97-141/pdfs/97-141.pdf [Accessed on June 2019]

[7] Haynes, S., Williams, K., Impact of seating posture on user comfort and typing performance for people with chronic low back pain, In: International Journal of Industrial Ergonomics, 2008, 38, 1, 35-46

[8] Choobinehet, A., et al., Musculoskeletal problems among workers of Iranian Rubber Factory, In: Journal of Occupational Health, 2007, 49, 418-423

[9] Nunes, I.L., Bush, P.M., Work-related musculoskeletal disorders assessment and prevention, In: Ergonomics - A systems Approach, INTECH Open Access Publisher, 2012

[10] Elsler, D., Takala, J., Remes, J., An international comparison of the cost of work-related accidents and illnesses, EU-OSHA, 2017, Available at: https://osha.europa.eu/en/tools-and-publications/publications/internationalcomparison-cost-work-related-accidents-and/view [Accessed on June 2019]

[11] Gomez-Baya, D., Lucia-Casademunt, A.M., A self $\square$ determination theory approach to health and well $\square$ being in the workplace: Results from the sixth European working conditions survey in Spain, In: ournal of Applied Social Psychology, 2018, 48, 5, 269-283

[12] Buckle, P., Ergonomics and musculoskeletal disorders: overview, In: Occupational Medicine, 2005, 55, 164-167

[13] Yelin, E., Weinstein, S., King, T., The Burden of Musculoskeletal Diseases in the United States, In: Seminars in arthritis and rheumatism, 2016, 46, 3, https://doi.org/10:1016/j.semarthrit.2016.07.013

[14] Qutubuddin, S.M., Hebbal, S.S., Kumar, A.C.S., Ergonomic Risk Assessment using Postural Analysis Tools in a Bus Body Building Unit, In: Industrial Engineering Letters, 2013, 3, 8, 10-19

[15] Kalınkara, V., Çekal, N., Akdoğan, I., Kacar, N., Anthropometric measurements related to the workplace design for female workers employed in the textiles sector in Denizli, Turkey, In: Eurasian Journal of Anthropology, 2011, 2, 2, $102-111$ 
[16] Pascual, S.A., Naqvi, S., An Investigation of Ergonomics Analysis Tools Used in Industry in the Identification of Work-Related Musculoskeletal Disorders, In: International Journal of Occupational Safety and Ergonomics, 2008, 14, 2, 237-245

[17] Mehta, R., Major health risk factors prevailing in garment manufacturing units of Jaipur, In: Journal of Ergonomics, $2012,2,2,1-3$

[18] Nieves Serratos-Perez, J., Mendiola-Anda, C., Musculoskeletal disorders among male sewing machine operators in shoemaking, In: Ergonomics, 1993, 36, 7, 793-800

[19] Kebede Deyyas, W., Tafese, A., Environmental and organizational factors associated with elbow/forearm and hand/wrist disorder among sewing machine operators of garment industry in Ethiopia, In: Journal of environmental and public health, 2014

[20] AL-Rammah, T.Y., Aloufi, A.S., Algaeed, S.K., Alogail, N.S., The prevalence of work-related musculoskeletal disorders among sonographers, In: Work: A Journal of Prevention, Assessment \& Rehabilitation, 2017, 57, 2, 211-219

[21] Kanat, S., et al., SWOT analysis of Pakistan's textile and clothing industry, In: Industria Textila, 2018, 69, 502-510, http://doi.org/10.35530/IT.069.06.1488

[22] Khan, W.A., Mustaq, T., Tabassum, A., Occupational Health, Safety and Risk Analysis, In: International Journal of Science, Environment and Technology, 2014, 3, 4, 1336-1346

[23] Roman-Liu, D., Comparison of concepts in easy-to-use methods for MSD risk assessment, In: Applied Ergonomics, 2014, 45, 420-427

[24] McAtamney, L., Corlett, E., RULA: a survey method for the investigation of work-related upper limb disorders, In: Applied Ergonomics, 1993, 24, 91-99

[25] Kee, D., Karwowski, W., LUBA: an assessment technique for postural loading on the upper body based on joint motion discomfort and maximum holding time, In: Applied Ergonomics, 2001, 32, 357-366

[26] Roman-Liu, D., Repetitive task indicator as a tool for assessment of upper limb musculoskeletal load induced by repetitive tasks, In: Ergonomics, 2007, 50, 11, 1740-1760

[27] Hignett, S., McAtamney, L., Rapid Entire Body Assessment (REBA), In: Applied Ergonomics, 2000, 31, 201-205

[28] Karhu, O., Kansi, P., Kuorinka, I., Correcting working postures in industry: a practical method for analysis, In: Applied Ergonomics, 1977, 8, 199-201

[29] Waters, T., Putz-Anderson, V., Garg, A., Fine, L., Revised NIOSH equation for the design and evaluation of manual lifting tasks, In: Ergonomics, 1993, 36, 749-766

[30] Al Madani, D., Dababneh, A., Rapid Entire Body Assessment: A Literature Review, In: American Journal of Engineering and Applied Sciences, 2016, 9, 1, 107-118

\section{Authors:}

\section{AFTAB AHMAD ${ }^{1,2}$, IQRA JAVED ${ }^{2,3}$, USAMA ABRAR ${ }^{1,4}$, ASHFAQ AHMAD $^{5}$ NASIF RAZA JAFFRI ${ }^{1,4}$, AMJAD HUSSAIN 6}

${ }^{1} \mathrm{NFC}$ Institute of Engineering and Fertilizers Research (NFC-IEFR), Department of Electrical Engineering, Faisalabad, Pakistan

2University of Engineering and Technology (UET), Department of Industrial and Manufacturing Engineering, Lahore, Pakistan

${ }^{3}$ University of Malaya, Department of Mechanical Engineering, Kuala Lumpur, Malaysia

${ }^{4}$ North China Electric Power University, School of Control and Computer Engineering, Beijing, China

5 University of Lahore, Department of Electronics and Electrical Systems, Lahore, Pakistan

${ }^{6}$ University of Engineering and Technology (UET), Department of Mechanical Engineering, Lahore, Pakistan

\section{Corresponding author:}

AFTAB AHMAD

e-mail: aftabahmadrao@gmail.com 